\title{
GAMBARAN PENGETAHUAN ANAK TENTANG JENIS MAKANAN KARIOGENIK TERHADAP TERJADINYA KARIES GIGI PADA SISWA/I KELAS V-B SD NEGERI 068003 KAYU MANIS PERUMNAS SIMALINGKAR MEDAN TUNTUNGAN
}

\author{
Sri Junita Nainggolan \\ Jurusan Keperawatan Gigi Poltekkes Kemenkes Medan
}

\begin{abstract}
Carcinogenic foods can cause tooth decay (dental caries). Carcinogenic food comes in the form of sweet food like candy, chocolate, cookies, sugar and other food which is starchy, sticky, carbohydrated and crumbled in the mouth. This research was a descriptive study with survey method aiming to find out the description of children's knowledge about kinds of carcinogenic food towards the occurrence of dental caries among grade 5b students at SDN 068003 Kayu Manis Perumnas Simalingkar Medan Tuntungan. The number of the samples was 35 students. The data were collected through the questionnaires and direct examination to the patients' oral cavity. The result showed that 30 students (85\%) had good knowledge about the types of cariogenic food and 5 students (15\%) had medium knowledge. Through the direct examination to 35 students, 24 students (68\%)had caries in milk teeth, 14 students (40\%) had caries in permanent teeth. It is expected that students choose healthy food and reduce consuming sweet foods that can lead to dental caries.
\end{abstract}

Keywords : Type of food Kariogenik, Dental caries

\section{PENDAHULUAN}

Pembangunan kesehatan adalah upaya yang dilaksanakan oleh semua orang dalam rangka meningkatkan kesadaran, kemauan, dan kemampuan hidup sehat agar terwujud derajat kesehatan masyarakat setinggi-tingginya. Kesehatan bagi anak tidak terlepas dari pengertian kesehatan pada umumnya. Kesehatan merupakan keadaan sejahtera dari badan, jiwa, dan sosial yang memungkinkan setiap orang hidup produktif secara sosial dan ekonomi (Notoatmodjo, 2003).

Untuk mencapai tujuan tersebut perlu diusahakan upaya kesehatan yang bersifat menyeluruh, terpadu, merata, dapat diterima serta terjangkau oleh seluruh lapisan masyarakat. Upaya-upaya kesehatan tersebut sesuai dengan bab IV pasal 47 Undang-undang nomor 36 tahun 2009 tentang kesehatan meliputi pencegahan penyakit (preventife), peningkatan kesehatan (promotif), penyembuhan penyakit (kuratif), dan pemulihan kesehatan (rehabilitatif) (Depkes RI, 2010).

Gigi dan gusi yang sehat merupakan bagian dari kesehatan umum yang baik. Kesehatan gigi dan gusi amat penting untuk menjamin status gizi yang baik, kemampuan bicara yang dapat dimengerti orang lain dan penampilan yang menarik. Gigi merupakan bagian terpenting dalam rongga mulut, karena adanya fungsi gigi yang tidak tergantikan, antara lain untuk mengunyah makanan sehingga membantu pencernaan untuk berbicara serta untuk menunjang penampilan (Mary E. Beck, 2011). .

Upaya pemeliharaan kesehatan gigi dan mulut serta pembinaan kesehatan gigi terutama pada kelompok anak sekolah perlu mendapat perhatian khusus, sebab pada usia ini anak sedang menjalani proses tumbuh kembang. Keadaan gigi sebelumnya akan berpengaruh terhadap perkembangan kesehatan gigi pada usia dewasa nanti (Febenti, 2014).

Negara berkembang seperti indonesia khususnya diperkotaan, masyarakatnya cenderung mengkonsumsi makanan lunak. Sedangkan di negara maju misalnya Amerika dan Jepang masyarakat banyak mengkonsumsi makanan berserat, sehingga angka kejadian karies lebih rendah dibandingan negara berkembang. Pengaturan konsumsi gula perlu diperhatikan karena gula yang tersisa pada mulut dapat memproduksi asam oleh bakteri (Budisuari, 2010).

Hasil penelitian Andayasari dan Anorital di Banten dan di Yogyakarta ditemukan adanya hubungan antara konsumsi makanan kariogenik dengan kejadian karies gigi. Hasil tersebut menunjukkan bahwa semakin sering mengkonsumsi makanan kariogenik, maka akan semakin tinggi indeks karies giginya (Andayasari dan Anorotal, 2016).

Usia 6-12 tahun merupakan kelompok usia yang sangat kritis terhadap terjadinya karies gigi permanen karena pada usia ini mempunyai sifat khusus yaitu masa transisi pergantian gigi susu ke gigi permanen. 
Karies gigi merupakan suatu penyakit jaringan keras gigi yang menyerang email, dentin, dan sementum yang ditandai dengan adanya demineralisasi jaringan keras gigi. Beberapa faktor utama penyebab karies yaitu mikroorganisme, permukaan gigi dan host, substrat dan waktu. Faktor substrat dan waktu biasanya sangat ditentukan oleh kebiasaan, seperti kebiasaan kebanyakan orang yang sering mengkonsumsi makanan yang kariogenik dan tidak membiasakan menyikat gigi dengan baik atau berkumur-kumur setelah makan. Kebiasaan ini menyebabkan sisa makanan yang masih menempel pada permukaan gigi terutama jenis sukrosa akan difermentasikan oleh mikroorganisme menjadi asam sehingga terjadi deminerilisasi email dan mempercepat proses perkembangan karies. Perkembangan karies juga dipengaruhi oleh sisa makanan yang tertinggal di dalam mulut dalam waktu yang lama. Karies mudah terjadi pada gigi yang memiliki permukaan pit dan fissure yang dalam, yang memudahkan plak menempel dan sukar dibersihkan. Kebersihan gigi yang buruk juga mempunyai resiko yang tinggi terhadap terjadinya karies gigi (Kidd dan Bechal, 2012).

Karies pada anak-anak biasanya dikarenakan kegemaran anak-anak mengkonsumsi makanan yang manis dan lengket dan kebiasaan menggosok gigi yang belum benar (Tamrin, 2014). Pola makan anak-anak yang mempunyai kecendrungan untuk memakan makanan kariogenik, serta kurangnya kesadaran dalam kedisiplinan dalam pemeliharaan kebersihan gigi dan mulut menyebabkan status kebersihan gigi dan mulut anak buruk sehingga prevelensi kariesnya tinggi (Alhamda, 2011).

Berdasarkan studi pendahuluan yang dilakukan peneliti di SDN 068003 Kayu Manis Perumnas Simalingkar tahun 2018 pada 10 orang siswa/i kelas V-B yang sering mengkonsumsi makanan kariogenik terdapat 8 orang siswa/i yang mengalami karies dan 2 orang siswa/i yang bebas karies, hal ini menunjukkan bahwa dari 10 orang siswa/i $80 \%$ gigi mengalami karies.

Berdasarkan latar belakang di atas penulis tertarik ingin meneliti tentang Gambaran Pengetahuan Anak Tentang Jenis Makanan Kariogenik Terhadap Terjadinya Karies Gigi Pada Siswa/i Kelas V-B SDN 068003 Kayu Manis Perumnas Simalingkar Medan Kecamatan Medan Tuntungan.

\section{Rumusan Masalah}

Untuk mengetahui bagaimana gambaran pengetahuan anak tentang jenis makanan kariogenik terhadap terjadinya karies gigi pada siswa/siswi kelas V-B SDN 068003 Kayu Manis Perumnas Simalingkar Medan Tuntungan.

\section{Tujuan Penelitian}

1. Untuk mengetahui pengetahuan anak tentang jenis makanan kariogenik terhadap terjadinya karies gigi pada siswa/i kelas V-B SDN 068003 Kayu Manis Perumnas Simalingkar Medan Tuntungan.
2. Untuk mengetahui status karies gigi pada siswa/i Kelas V-B SDN 068003 Kayu Manis Perumnas Simalingkar Medan tuntungan.

\section{METODE PENELITIAN}

\section{Jenis Penelitian}

Jenis penelitian yang dilakukan adalah penelitian deskriptif dengan metode survey yang bertujuan untuk mengetahui Gambaran Pengetahuan Anak Tentang Jenis Makanan Kariogenik Terhadap Terjadinya Karies Gigi Pada siswa/i Kelas V-B SDN 068003 Kayu Manis Perumnas Simalingkar Medan Tuntungan

\section{Populasi dan Sampel Penelitian}

siswa/i kelas V-B SDN 068003 Kayu Manis Perumnas Simalingkar Medan Tuntungan yaitu berjumlah 35 orang.

\section{Jenis dan Cara pengumpulan Data}

1. Data primer adalah data yang diperoleh langsung dari siswa/i untuk mengetahui gambaran pengetahuan tentang jenis makanan kariogenik diperoleh melalui kuesioner. Sedangkan data tentang karies diperoleh dari pemeriksaan langsung pada siswa/i.

2. Data sekunder adalah data yang diperoleh dari administrasi sekolah untuk mendapatkan nama dan umur siswa/i.

Pengumpulan data yang dilakukan dalam penelitian yaitu, dengan membagi kuesioner yang berisi 12 pertanyaan kepada siswa/siswi. Setelah seluruh pertanyaan dalam kuesioner di jawab oleh siswa/siswi maka data yang telah di isi akan disederhanakan untuk mempermudah pengolahan data. Setelah kuesioner di isi oleh siswa/siswi peneliti mengumpulkan dan memberitahukan jawaban yang benar dari seluruh pertanyaan.

1. Untuk jawaban yang benar, diberikan skor 1 (satu)

2. Untuk menjawab yang salah, diberikan skor 0 (nol) Untuk memperoleh kriteria tingkat pengetahuan digunakan rumus sebagai berikut :

Rumus $=$

$\underline{\text { Skor maksimum - skor minimum }}$ 3

$$
\begin{aligned}
& =\frac{2-0}{3} \\
& =4
\end{aligned}
$$

Kriteria pengetahuan yang digunakan adalah :

$$
\begin{array}{llll}
\text { - } & \text { Baik } & & =9-12 \\
\text { - } & \text { Sedang } & & =5-8 \\
\text { - } & \text { Buruk } & & =0-4 \\
& \text { Setelah } & \text { semuanya terkumpul, selanjutnya }
\end{array}
$$
peneliti memeriksa keadaan kesehatan gigi dan mulut responden dengan menggunakan alat dan bahan yaitu:

1. Alat yang digunakan
a. Sonde
b. Excavator
c. Kaca mulut 
d. Pinset

e. Gelas kumur

f. Nier beken

2. Bahan yang digunakan

a. Alkohol untuk desinfeksi alat

b. Kapas

c. Betadhine

d. Air untuk kumur

Dalam pemeriksaan status karies gigi responden, peneliti membentuk tim. Tim terdiri dari 2 orang, dimana kegiatan ini terdiri dari :

1. Orang pertama bertugas untuk menyediakan alat serta bahan yang digunakan dalam melakukan pemeriksaan sampel.

2. Orang kedua bertugas mencatat hasil pemeriksaan dan dicatat di formulir pemeriksaan.

Selanjutnya peneliti melakukan tahapan pengumpulan data dengan pemeriksaan rongga mulut responden yaitu :

1. Peneliti menyiapkan alat dan bahan yang di butuhkan dalam pemeriksaan rongga mulut responden.

2. Setelah semua alat dan bahan siap, orang kedua memanggil responden satu persatu yang akan diperiksa.

3. Kemudian peneliti memeriksa rongga mulut responden dengan instrumen kaca mulut dan sonde.

4. Pemeriksaan dilakukan oleh peneliti dimulai dari gigi posterior kanan atas lalu ke gigi anterior atas kemudian ke gigi posterior kiri atas, setelah itu ke gigi posterior kiri bawah kemudian anterior bawah dan posterior kanan bawah.

5. Orang kedua mencatat status karies gigi pada format pemeriksaan sesuai instruksi peneliti.

6. Kemudian data yang diperoleh dimasukkan ke dalam master tabel.

\section{Pengolahan dan Analisa Data}

1. Proses editing

Proses editing dilakukan dengan memeriksa kuesioner yang telah diisi dengan tujuan data yang masuk dapat diolah secara benar sehingga pengolahan data memberi hasil yang menggambarkan masalah yang diteliti. Kemudian data dikelompokkan dengan menggunakan aspek pengukuran.

2. Proseses coding

Di lakukan dengan merubah jawaban responden ke dalam bentuk angka-angka sehingga mempermudah dalam pengolahan data.

3. Proses tabulating

Memasukkan data penelitian ke dalam tabel untuk mempermudah analisa data pengolahan data serta pengambilan kesimpulan.

Data yang di kumpulkan diolah secara manual, kuesioner yang telah diberikan dikumpulkan, diperiksa kelengkapan ada tidaknya jawaban yang tidak dijawab untuk memberikan informasi mengenai tingkat pengetahuan anak tentang jenis makanan kariogenik terhadap terjadinya karies pada siswa/siswi kelas V-B
SDN 068003 Kayu Manis Perumnas Simalingkar Medan Tuntungan.

\section{HASIL PENELITIAN}

Setelah seluruh data terkumpul, maka dilakukan analisis data dengan membuat tabel distribusi frekuensi sebagai berikut :

Tabel 4.1

Distribusi Frekuensi Pengetahuan Anak Tentang Jenis Makanan Kariogenik Terhadap Terjadinya Karies Gigi

Pada Siswa/i Kelas V-B SDN 068003 Kayu Manis Perumnas Simalingkar Medan Tuntungan

\begin{tabular}{|c|c|c|}
\hline $\begin{array}{c}\text { Kriteria } \\
\text { pengetahuan }\end{array}$ & $\mathrm{N}$ & $\%$ \\
\hline Baik & 30 & 85 \\
\hline Sedang & 5 & 15 \\
\hline Bueuk & 0 & 0 \\
\hline jumlah & 35 & 100 \\
\hline
\end{tabular}

Dari tabel 4.1 dapat diketahui bahwa 35 orang siswa/i kelas V-B SDN 068003 Kayu Manis Perumnas Simalingkar Medan Tuntungan sebanyak 30 orang (85\%) memiliki pengetahuan baik, 5 orang $(15 \%)$ memiliki pengetahuan sedang, dan 0 memiliki pengetahuan buruk.

Tabel 4.2

Distribusi Frekuensi Rata-rata Karies Gigi def-t Pada Siswa/i Kelas V-B SDN 068003 Kayu Manis Perumnas Simalingkar Medan Tuntungan

\begin{tabular}{|c|c|c|c|}
\hline Gigi indeks & Jumlah def.t & f & $\%$ \\
\hline $\mathrm{d}$ & 12 & 24 & 68 \\
\hline $\mathrm{e}$ & 1 & 18 & 51 \\
\hline $\mathrm{f}$ & 1 & 1 & 2 \\
\hline Jumlah & 43 & 35 & 100 \\
\hline
\end{tabular}

Dari tabel 4.2 dapat diketahui bahwa dari 35 siswa/i kelas V-B SDN 068003 Kayu Manis Perumnas Simalingkar Medan Tuntungan memiliki d (decay) 24 orang (68\%), e (extraktion) 18 orang (51\%), f (filling) 1 orang $(2 \%)$ dan def-t ada 27 orang $(77 \%)$.

Tabel 4.3

Distribusi Responden Menutut Frekuensi Rata-rata Karies Gigi DMF-T Pada Siswa/i Kelas V-B SDN 068003 Kayu Manis Perumnas Simalingkar Medan Tuntungan

\begin{tabular}{|c|c|c|}
\hline Gigi Indeks & Jumlah DMF.T & $\%$ \\
\hline D & 14 & 40 \\
\hline M & 0 & 0 \\
\hline F & 0 & 0 \\
\hline DMF.T & 14 & 40 \\
\hline
\end{tabular}

Dari tabel 4.3 dapat diketahui bahwa dari 35 siswa/i kelas V-B SDN 068003 Kayu Manis Perumnas Simalingkar Medan Tuntungan memiliki D (Decay) 14 orang (40\%), M (Missing) tidak ada, F (Filling) tidak ada, dan DMF-T 14 orang (40\%). 
Tabel 4.4

Distribusi Frekuensi Status Karies Gigi Siswa/i Kelas V-B SDN 068003 Kayu Manis Perumnas Simalingkar Medan Tuntungan

\begin{tabular}{|c|c|c|c|}
\hline $\begin{array}{c}\text { Status } \\
\text { Karies }\end{array}$ & Jumlah d.D & $\mathrm{N}$ & Rata-rata \\
\hline $\mathrm{d}$ & 24 & 35 & 1.08 \\
\hline $\mathrm{D}$ & 14 & & \\
\hline
\end{tabular}

Dari tabel 4.4 dapat diketahui bahwa siswa/i kelas V-B SDN 068003 Kayu Manis Perumnas Simalingkar Medan Tuntungan jumlah rata-rata karies gigi 1,08.

\section{PEMBAHASAN}

Pengetahuan adalah hasil dari tahu dan ini terjadi setelah orang melakukan pengindraan (mata, hidung, telinga dan sebagainya) terhadap suatu objek. Sebagian besar pengetahuan seseorang diperoleh melalui indra pendengaran yaitu telinga dan indra penglihatan yaitu mata (Notoatmodjo, 2012).

Berdasarkan kuesioner yang diberikan, diperoleh data bahwa $97 \%$ siswa/i mengetahui apa itu makanan manis, dan 94\% siswa/i mengetahui dampak/akibat sering memakan makanan manis. Makanan Kariogenik berupa makanan manis seperti permen, coklat, kue-kue, dan lainlain termasuk makanan berkarbohidrat yang berbentuk tepung atau cairan yang bersifat lengket serta hancur didalam mulut. Makanan manis tersebut dapat menyebabkan terjadinya karies karena ada kaitannya antara karbohidrat dengan pembentukan plak pada permukaan gigi (Riani, 2005). Sebagian plak didalam gigi ini mengubah gula dan karbohidrat yang berasal dari makanan dan minuman yang masih menempel di gigi menjadi asam yang bisa merusak gigi dengan cara melarutkan mineral-mineral yang ada di dalam gigi atau terjadi deminerilisasi ( Mclyntyre, 2005).

Berdasarkan kuesioner yang diberikan 94\% siswa/i mengetahui penyebab gigi berlubang yaitu seringnya mengkonsumsi makanan manis disertai jarangnya menggosok gigi. Karies gigi atau gigi berlubang terjadi dari deminerilisasi asam yang melebihi air liur dan reminerilisasi fluorida, dan hampir semua deminerilisasi asam terjadi dimana makanan (yang mengandung karbohidrat seperti gula atau makanan yang manis) yang tersisa pada gigi. Meskipun sebagian besar makanan terperangkap tersisa diantara gigi, lebih $80 \%$ dari gigi berlubang terjadi didalam pit dan fissure dimana menyikat gigi, fluorida, dan air liur tidak bisa mencapai daerah tersebut (Yundali, 2012).

Berdasarkan kuesioner yang diberikan 94\% siswa/i mengetahui bahwa kebiasaan yang baik setelah makan makanan yang manis adalah berkumur dan menggosok gigi dengan benar. Permatasari (2014) menjelaskan menyikat gigi langsung setelah makan dapat menyebabkan permukaan email yang pori-porinya sedang melebar akibat kondisi mulut yang sedang asam, menjadi lebih mudah terkikis oleh efek mekanik dari penyikatan gigi. Setelah makan, sebaiknya berkumur-kumur terlebih dahulu. Tunggu setengah hingga satu jam, hingga kondisi mulut netral oleh efek buffer dari air liur (saliva), kemudian dilakukan penyikatan gigi.

Hasil penelitian pada tabel 4.1 yaitu pengetahuan anak tentang jenis makanan kariogenik terhadap terjadinya karies gigi pada 35 orang siswa/i kelas V-B SDN 068003 Kayu Manis Perumnas Simalingkar Medan, terdapat 30 orang $(85 \%)$ memiliki pengetahuan baik, dan sebanyak 5 orang $(15 \%)$ memiliki pengetahuan yang sedang.

Dilihat dari hasil pemeriksaan kuesioner, sebanyak 7 orang (20\%) siswa/i menjawab salah mengenai apa itu makanan kariogenik, mereka beranggapan bahwa makanan kariogenik adalah makanan yang disukai banyak orang. Menurut Riani (2005) Makanan kariogenik adalah makanan yang dapat menyebabkan terjadinya kerusakan gigi (karies gigi).

Dan sebanyak 13 orang (37\%) menjawab salah tentang jenis makanan apa yang dapat memperkuat kesehatan gigi, mereka beranggapan bahwa pisang, mangga, dan salak makanan yang dapat memperkuat gigi. Beberapa makanan dan minuman asam mungkin dapat menyebabkan pengikisan enamel, jadi untuk membuat gigi menjadi kuat kembali perlu untuk menambahkan mineral lagi, yaitu dengan mengkonsumsi makanan yang kaya akan kalsium dan fosfor. Kalsium dan fosfor adalah zat yang akan membangun dinding enamel dan menjaga gigi kuat dan sehat. Contoh sumber kalsium adalah yougurt, keju, makanan laut, susu (rendah lemak), tahu, dan kacang almon. Sedangkan contoh sumber fosfor adalah biji labu kuning, ikan, daging merah, telur, dan tahu (Shiny Smile Dental clinic, 2014).

Indeks adalah ukuran yang dinyatakan dengan angka dari keadaan suatu golongan atau kelompok terhadap suatu penyakit gigi tertentu. Ukuran-ukuran ini dapat digunakan untuk mengukur derajat keparahan dari suatu penyakit mulai dari yang ringan sampai berat (Pintauli dan Hamada.2008).

Dari tabel 4.2 dapat diketahui bahwa dari 35 siswa/i kelas V-B SDN 068003 Kayu Manis Perumnas Simalingkar Medan Tuntungan memiliki d (decay) 24 orang (68\%), e (extraktion) 18 orang (51\%), f (filling) 1 orang (2\%) dan def-t ada 27 orang (77\%).

Dari tabel 4.3 dapat diketahui bahwa dari 35 siswa/i kelas V-B SDN 068003 Kayu Manis Perumnas Simalingkar Medan Tuntungan memiliki D (Decay) 14 orang (40\%), M (Missing) tidak ada, F (Filling) tidak ada, dan DMF-T 14 orang (40\%).

Karies gigi adalah penyakit jaringan gigi yang ditandai dengan kerusakan jaringan, dimulai dari permukaan gigi. Karies gigi dapat dialami oleh setiap orang dan dapat timbul pada satu permukaan gigi, misalnya dari email ke dentin atau ke pulpa (Rasinta Tarigan, 2014).Dari tabel 4.4 dapat diketahui bahwa siswa/i kelas V-B SDN 068003 Kayu Manis Perumnas Simalingkar Medan Tuntungan jumlah rata-rata karies gigi 1,08 .

Hasil penelitian Andayasari dan Anorital di Banten dan di Yogyakarta ditemukan adanya hubungan antara konsumsi makanan kariogenik dengan kejadian karies gigi. Hasil tersebut menunjukkan bahwa semakin 
sering mengkonsumsi makanan kariogenik, maka akan semakin tinggi indeks karies giginya (Andayasari dan Anorotal, 2016).

Pengetahuan siswa/i memang baik/sedang, namun pengetahuan responden hanya sekedar tahu (know), menurut Soekidjo Notoatmodjo (2012) yakni hanya sekedar mengetahui belum sampai pada tahap aplikasi sehingga meskipun pengetahuan responden cukup baik namun anak tetap mengalami karies gigi.

Karies pada anak-anak biasanya dikarenakan kegemaran anak-anak mengkonsumsi makanan yang manis dan lengket dan kebiasaan menggosok gigi yang belum benar. Pola makan anak-anak yang mempunyai kecendrungan untuk memakan makanan kariogenik, serta kurangnya kesadaran dan kedisiplinan dalam pemeliharaan kebersihan gigi dan mulut menyebabkan status kebersihan gigi dan mulut anak buruk sehingga prevelensi kariesnya tinggi.

\section{SIMPULAN}

1. Pengetahuan anak tentang makanan kariogenik terhadap terjadinya karies gigi pada siswa/i kelas VB SDN 068003 Kayu Manis Perumnas Simalingkar Medan Tuntungan sudah terbukti baik dengan hasil kategori baik 30 orang $(85 \%)$, sedang 5 orang (15\%) dan yang buruk tidak ada.

2. Status karies gigi pada siswa/i kelas V-B SDN 068003 Kayu Manis Perumnas Simalingkar Medan Tuntungan dari 35 orang diperoleh data d (decay) 24 orang (68\%),D (Decay) 14 orang (40\%).

3. Siswa/i kelas V-B SDN 068003 Kayu Manis Perumnas Simalingkar Medan Tuntungan memiliki pengetahuan baik, namun dalam hal pelaksanaan /tindakan masih kurang.

\section{SARAN}

1. Diharapkan pihak sekolah melakukan kerja sama dengan pihak puskesmas untuk melakukan Usaha Kesehatan Gigi Sekolah (UKSG) dalam upaya meningkatkan kesehatan gigi.

2. Diharapkan kepada siswa/i agar memilih makanan yang menyehatkan gigi yang termasuk salah satu untuk mencegah terjadinya karies gigi.

3. Agar dilakukan penelitian lebih lanjut mengenai gambaran pengetahuan anak tentang makanan kariogenik terhadap terjadinya karies gigi.

\section{DAFTAR PUSTAKA}

Alhamda, S. (2011). Status Kebersihan Gigi dan Mulur dengan Status Karies Gigi (Kajian pada Murid Kelompok Umur 12 Tahun di Sekolah Dasar Negeri Kota Bukit Tinggi) . Berita Kedokteran Masyarakat.

Andayasari, L. Dan Anorital. 2016. Hubungan Konsumsi Makanan Kariogenik dengan Status Kesehatan Gigi Anak Taman Kanak-kanak di Provinsi Banten dan Daerah Istimewa Yogyakarta . Prosiding SNaPP 2016 Kesehatan.

Arisman, 2007. Gizi dalam Daur Kehidupan, Jakarta : EGC

Beck. M. E. 2011. Ilmu Gizi dan Diet, Yogyakarta : Yem Cipta

Budisuari, M, A 2010. Hubungan Pola Makan dan Kebiasaan Menyikat gigi dengan Kesehatan Gigi dan Mulut (Karie) di Indonesia. Buletin Penelitian Sistem Kesehatan.

Erwana, F, A, 2013. Kesehatan Gigi dan Mulut, Yogyakarta : ANDI OFFSET

Febenty, A. Hubungan Konsumsi Makanan Kariogenik dan Frekuensi Menggosok Gigi dengan Kejadian Karies Gigi Pada Anak Kelas III di SDN Kasihan Yogyakarta: Ilmu Keperawatan Sekolah Tinggi Ilmu Kesehatan Jendral Achmad Yani Yogyakarta 2014.

Kidd, Edwina, A, M. 2008. Dasar-dasar Karies Penyakit dan Penanggulangannya, Jakarta : EGC

Kidd, E. A. M dan Bechal, S. J. 2012. Dasar-dasar Karies, Penyakit dan Penanggulangannya. Jakarta : Buku Kedokteran EGC

Machfoedz, I. 2008. Menjaga Kesehatan Gigi dan Mulut Anak-anak dan Ibu Hamil, Yogyakarta : Fitramaya

Mclyntyre, JM. 2005. Dental Cares The Major Cause of Dental Damage, Queensland: Knowledge book and Software.

Notoadmodjo, S. 2010. Ilmu Perilaku Kesehatan, Jakarta : Rineka Cipta

2003. Promosi Kesehatan Teori dan Aplikasi, Jakarta: Media Aesculapius

Pintauli, S, dan T Hamada. 2008. Menuju gigi dan Mulut Sehat: Pencegahan dan Pemeliharaan, Medan : USU

Permatasari, R. 2014. Gigi Sensitif. Apa Penyebabnya?, Jakarta : Health First Magazine Rumah Sakit Pondok Indah Group: 22.

Riani. D. Sarasati. 2005. Peranan Pola Makan Terhadap Karies Gigi pada Anak : PDGI

Tamrin, M, 2014. Dampak Konsumsi Makanan Kariogenik Kebiasaan Menyikat Gigi Terhadap Terjadinya Kejadian Karies Gigi Pada Anak Sekolah. Journal of Pediatric Nursing.

Tarigan, S. 2013. Karies Gigi, Jakarta : EBC.

Yundali, S. 2012. Kesehatan Gigi dan Mulut, Bandung : Reka Cipta

http://sireka.pom.go.id/requirement/UU-36-2009Kesehatan.pdf.

http://www.shinysmiledentalclinic.com/tiga-puluh-30jenis-makanan-terbaik-untuk-kesehatan-gigi-dangusi/ Prasko17.blogspot.co.id/2012/09/indeks-kariesgigi-dmf-t-def-t.html?m=1 